\title{
KEEFEKTIFAN BIMBINGAN TES DALAM MENGATASI KETIMPANGAN SKOR TES AKUNTANSI DITINJAU DARI KECEMASAN SISWA
}

Oleh: Jafar Ahiri

\section{Abstrak}

Penelitian ini bertujuan untuk mengetahui keefektifan bimbingan tes dalam mengatasi ketimpangan skor tes Akuntansi ditinjau dari kecemasan siswa. Penelitian dilaksanakan pada tahun ajaran 2003/2004 dengan sampel siswa-siswi kelas satu semester satu SMUN 18 dan SMUN 15 di Jakarta Utara, Jumlah sampel 200 siswa dipilih secara acak sederhana. Dalam penelitian ini digunakan rancangan eksperimen faktorial $2 \times 3$ dengan melibatkan satu variabel terikat yaitu ketimpangan skor tes Mata Pelajaran Akuntansi, serta dua variabel bebas yaitu bimbingan tes sebagai variabel perlakuan dan kecemasan tes sebagai variabel kontrol. Temuan dalam penelitian adalah: (1) ketimpangan skor tes Akuntansi siswa yang memperoleh bimbingan kiat dalam menjawab tes lebih tinggi dari siswa yang memperoleh bimbingan stabilisasi kecemasan tes; (2) ketimpangan skor tes Akuntansi siswa yang memiliki kecemasan tes tinggi paling tinggi di antara siswa yang memiliki kecemasan tes rendah dan sedang; (3) pada pemberian bimbingan kiat dalam menjawab tes, ketimpangan skor tes Akuntansi siswa yang memiliki kecemasan tes tinggi paling tinggi di antara siswa yang memiliki kecemasan tes rendah dan sedang; (4) pada pemberian bimbingan stabilisasi kecemasan tes, ketimpangan skor tes Akuntansi siswa yang memiliki kecemasan tes tinggi paling tinggi di antara siswa yang memiliki kecemasan tes sedang dan rendah; (5) pada

*) Dr.Jafar Ahiri adalah Dosen FKIP Universitas Haluoleo Kendari, Sulawesi Tenggara. 
kecemasan tes tinggi, ketimpangan skor tes Akuntansi siswa yang memperoleh bimbingan kiat dalam menjawab tes lebih tinggi dari siswa yang memperoleh bimbingan stabilisasi kecemasan tes; (6) pada kecemasan tes sedang, ketimpangan skor tes Akuntansi siswa yang memperoleh bimbingan kiat dalam menjawab tes lebih rendah dari siswa yang memperoleh bimbingan stabilisasi kecemasan tes; (7) pada kecemasan tes rendah, ketimpangan skor tes Akuntansi siswa yang memperoleh bimbingan kiat dalam menjawab tes lebih tinggi dari siswa yang memperoleh bimbingan stabilisasi kecemasan tes; (8) terdapat pengaruh interaksi antara bimbingan tes dengan kecemasan tes terhadap ketimpangan skor tes Akuntansi siswa.

Kata kunci: Bimbingan, kecemasan, skor tes, dan akuntansi.

\section{A. LATAR BELAKANG}

Penggunaan tes sebagai alat evaluasi dapat memotivasi siswa untuk belajar. Sebagian siswa termotivasi untuk belajar lebih giat, sebagian motivasinya menurun, dan sebagian lagi tidak perduli. Motivasi belajar dapat mempengaruhi mutu hasil pembelajaran, salah satu indikatornya adalah peningkatan hasil belajar. Hasil belajar yang berkualitas merupakan tujuan utama pembelajaran berbagai mata pelajaran pada berbagai jenjang pendidikan. Demikian pula pada mata pelajaran Akuntansi yang merupakan pokok bahasan dalam penelitian ini.

Upaya pencapaian tujuan dan meningkatkan kualitas hasil belajar Akuntansi terus dikembangkan, misalnya penyempurnaan kurikulum, peningkatan kemampuan guru, dan penyediaan buku ajar. Namun sejauh ini hasil belajar Akuntansi secara umum masih tergolong rendah. Demikian pula hasil belajar Akuntansi yang rendah tersebut masih dapat dipertanyakan kualitasnya. Apakah kinerja siswa dalam tes hasil belajar Akuntansi terbebas dari 
ketimpangan pengukuran? Apakah hasil-hasil tersebut murni merupakan indikator pengetahuan siswa? Kenyataannya hampir semua tes tidak pernah terlepas dari pengaruh ketimpangan pengukuran atau bias. Demikian pula, situasi pengetesan itu sendiri dapat membangkitkan kecemasan yang juga merupakan salah satu faktor penyebab rendahnya hasil tes. Akibatnya hasil-hasil tes tidak dapat digunakan sepenuhnya sebagai ukuran kualitas siswa.

Persepsi siswa terhadap situasi pengetesan dapat membentuk reaksi mereka terhadap tes. Beberapa siswa yang termotivasi baik, menganggap tes sebagai suatu tantangan, sementara siswa-siswa lainnya yang tidak termotivasi dengan baik menganggap tes sebagai suatu ancaman. Akibat dari anggapan bahwa tes sebagai suatu ancaman maka timbullah suatu tanggapan tertentu terhadap tes, yang disebut kecemasan tes.

Kecemasan tes bersumber dari aspek psikologis siswa. Dalam menghadapi tes, setiap siswa akan merasakan tingkat kecemasan tertentu baik berupa kecemasan tinggi, sedang, ataupun rendah. Akibat kecemasan tersebut, peserta tes mungkin akan memperoleh skor tes yang tidak sesuai dengan kemampuannya, kendatipun semua butir tes valid. Peserta tes dapat saja memperoleh skor yang lebih tinggi dari skor yang seharusnya diperoleh berdasarkan kemampuannya atau sebaliknya dapat pula memperoleh skor yang lebih rendah dari kemampuannya. Dalam hal ini telah terjadi ketimpangan skor tes.

Dalam pengukuran pendidikan, ketimpangan skor tes perlu dicegah atau dihindari. Apabila terjadinya ketimpangan skor tes tidak dapat dicegah atau dihindari, maka perlu dilakukan upaya pendeteksian atas ketimpangan tersebut. Sehingga dari hasil deteksi dapat diambil suatu keputusan yang tepat tentang apa yang harus dilakukan terhadap skor yang dicapai siswa dalam suatu tes hasil belajar. 


\section{B. TUJUAN PENELITIAN}

Penelitian ini bertujuan untuk mendeskripsikan: (1) Perbedaan ketimpangan skor tes Akuntansi siswa yang memperoleh bimbingan kiat dalam menjawab tes dan siswa yang memperoleh bimbingan stabilisasi kecemasan tes; (2) Perbedaan ketimpangan skor tes Akuntansi siswa yang memiliki kecemasan tes tinggi, sedang, dan rendah; (3) Perbedaan ketimpangan skor tes Akuntansi siswa yang memiliki kecemasan tes tinggi, sedang, dan rendah yang memperoleh bimbingan kiat dalam menjawab tes; (4) Perbedaan ketimpangan skor tes Akuntansi siswa yang memiliki kecemasan tes tinggi, sedang, dan rendah yang memperoleh bimbingan stabilisasi kecemasan tes; (5) Perbedaan ketimpangan skor tes Akuntansi siswa yang memiliki kecemasan tes tinggi yang memperoleh bimbingan kiat dalam menjawab tes dengan siswa yang memperoleh bimbingan stabilisasi kecemasan tes; (6) Perbedaan ketimpangan skor tes Akuntansi siswa yang memiliki kecemasan tes sedang yang memperoleh bimbingan kiat dalam menjawab tes dengan yang memperoleh bimbingan stabilisasi kecemasan tes; (7) Perbedaan ketimpangan skor tes Akuntansi siswa yang memiliki kecemasan tes rendah yang memperoleh bimbingan kiat dalam menjawab tes dengan siswa yang memperoleh bimbingan stabilisasi kecemasan tes; (8) Pengaruh interaksi antara bimbingan tes dengan kecemasan tes terhadap ketimpangan skor tes Akuntansi.

\section{KAJIAN TEORI}

\section{Bimbingan Tes}

Bimbingan tes dilaksanakan untuk mengajarkan beberapa jenis keahlian yang dibutuhkan siswa dalam menyelesaikan tes, khususnya tes buatan guru ataupun tes yang dipublikasikan. Kaminski dalam Sweetnam (2004) menjelaskan bahwa tujuan bimbingan persiapan tes secara umum adalah: (1) pengajaran umum atas tujuan tertentu yang tidak diukur oleh tes; (2) pengajaran keahlian dalam menyelesaikan tes; (3) pengajaran tujuan yang dipilih oleh organisasi komersiil dan tujuan dari 
berbagai tes baku; (4) pengajaran tujuan tes baku yang akan diteskan; (5) latihan dalam menyelesaikan bentuk-bentuk tes paralel yang dipublikasikan; (6) latihan dalam menyelesaikan tes yang sama.

Bimbingan penyelesaian tes dapat meningkatkan kesadaran dan percaya diri siswa sehingga mereka dapat menyelesaikan tes dengan penuh percaya diri dan lebih peduli terhadap butirbutir tes. Setelah siswa-siswa dilatih teknik penyelesaian tes maka mereka dapat menerapkannya dalam situasi tes yang sebenarnya. Mereka dapat mengatur waktu dan menganalisis kata-kata kunci dalam tes secara lebih efektif (Vattanapath dan Jaiprayoon, 2004).

Berdasarkan beberapa pendapat di atas dapat disimpulkan bahwa bimbingan tes adalah pembelajaran pengetahuan, keahlian, dan strategi dalam menjawab tes hasil belajar, yang terdiri atas: (1) persiapan tes secara intelektual; (2) kiat dalam menjawab tes; dan (3) stabilisasi kecemasan tes. Bimbingan tes bertujuan untuk meningkatkan kemampuan siswa dalam menjawab tes dan untuk memastikan bahwa siswa benar-benar mengetahui: apa itu tes, bagaimana tes itu disusun, bagaimana menggunakan waktu yang terbatas secara efektif, bagaimana menjawab berbagai jenis pertanyaan, dan kapan tebakan dapat dilakukan. Untuk mengungkapkan unsur-unsur bimbingan tes secara lebih mendalam, maka kajian selanjutnya akan difokuskan pada bimbingan kiat dalam menjawab tes.

Kiat dalam menjawab tes mencakup kemampuan siswa untuk mengetahui kelemahan guru dalam mengembangkan tes. Jadi pembahasan tentang kiat dalam menjawab tes ini akan dapat membantu guru dalam menghindari kelemahannya ketika mengembangkan tes, terutama pada bentuk tes pilihan ganda. Kiat dalam menjawab tes yang utama mencakup bagaimana bekerja secara produktif ketika menyelesaikan tes, misalnya bagaimana menggunakan waktu secara efektif dan bagaimana 
menghindari kesalahan. Kebanyakan siswa mempelajari kiat dalam menjawab tes dengan caranya sendiri, tanpa melalui bimbingan guru. Sejumlah siswa, khususnya yang berkemampuan rendah atau dari budaya yang berbeda akan memperoleh manfaat dari pengetahuan kiat dalam menjawab tes (Oosterhof, 1999).

Bimbingan kiat dalam menjawab tes sangat penting dan bermanfaat, terutama dalam situasi di mana peserta tes kekurangan informasi tentang teknik menjawab tes yang paling efekif. Karenanya, pengetahuan tentang kiat-kiat menjawab tes sangat bermanfaat dalam menangani situasi semacam ini. Prinsip-prinsip kiat dalam menjawab tes dapat diajarkan di kelas guna meningkatkan kinerja siswa dalam tes hasil belajar. Dolly dan Williams seperti dikutip oleh Haniza (2003) menjelaskan bahwa strategi kognitif yang menjadi bagian dari kiat dalam menjawab tes, memungkinkan untuk diajarkan kepada siswa.

Program bimbingan tes berbeda antara satu bimbingan dengan bimbingan yang lainnya, terutama dipandang dari segi metode, jangka waktu, dan tujuannya. Namun secara umum dapat disimpulkan bahwa bimbingan tes adalah suatu program pengajaran jangka pendek yang difokuskan pada beberapa faktor berikut baik sendiri-sendiri ataupun bersama-sama, yaitu: (1) Pembelajaran materi pokok tes; (2) Pembelajaran dan latihan kiat dalam menjawab tes; (3) Pembelajaran dan latihan stabilisasi kecemasan tes; dan (4) Pembiasaan terhadap media pengetesan.

Teori-teori tentang bimbingan kiat dalam menjawab tes yang telah diuraikan dapat disimpulkan bahwa, kiat dalam menjawab tes merupakan kemampuan untuk menunjukkan keahlian dalam menyelesaikan tes dengan memanfaatkan format dan karakteristik tes dan atau situasi pelaksanaan tes guna memaksimalkan pencapaian skor tes. Sedangkan bimbingan 
kiat dalam menjawab tes adalah pembelajaran dan latihan singkat tentang tata-cara atau teknik dalam menjawab tes guna membantu siswa sehubungan dengan: (1) cara menghindari kesalahan; latihan memahami petunjuk tes, memahami sasaran ukur butir-butir tes, menjawab butir tes dengan mendahulukan pertanyaan yang mudah, serta menjawab semua butir tes; (2) cara menggunakan waktu secara efektif, yaitu memastikan berapa waktu yang diperlukan, mulai bekerja secepat mungkin, bekerja secara cepat dan hati-hati; (3) teknik pertimbangan secara deduktif, dan penggunaan isyarat; yaitu latihan menjawab butir-butir tes dengan memanfaatkan isyarat atau prunjuk-petunjuk tertentu dalam pokok soal dan dalam pilihan jawabannya; (4) cara menebak; latihan teknik menebak secara tepat sehingga memberikan peluang benar yang lebih tinggi.

\section{Kecemasan Tes}

Hampir semua siswa mengalami kecemasan tes. Pada sebagian siswa kecemasan pada tingkat tertentu merupakan pendorong kinerja yang efektif, dan pada siswa lainnya dapat menjadi penyebab kinerja yang tidak efektif. Hal ini berarti bahwa kecemasan tes tidak selamanya merugikan siswa. Untuk itu, menurut Sarason, et al. (1960) dalam kajian kecemasan tes siswa perlu mempertimbangkan beberapa hal, yaitu: (1) situasi tes dialami hampir semua orang baik dalam sekolah ataupun dalam lingkungan masyarakat; (2) pemberi tes dan peserta tes (individu atau kelompok) sering mengalami situasi tes untuk tujuan evaluasi, dan dalam hal ini penting untuk berbuat lebih baik, kendatipun istilah "lebih baik" diartikan berbeda oleh peserta tes dan pemberi tes; dan (3) dalam budaya kita kehidupan manusia sangat dipengaruhi oleh kinerja dalam tes. Jadi tidak berlebihan apabila dikatakan bahwa kualitas atau kinerja dalam tes merupakan salah satu penentu utama kehidupan seseorang dalam masyarakat.

Siswa-siswa yang mengalami kecemasan tes menunjukkan 
gejala-gejala tertentu yang dapat diidentifikasi dalam pelaksanaan tes. Mengetahui gejala-gejala kecemasan tes adalah merupakan langkah pertama dalam mengatasinya. Gejala-gejala yang menunjukkan kecemasan tes adalah: (1) merasakan tes lebih sebagai ancaman dari pada sebagai tantangan; (2) merasa sangat kuatir atau berpikiran negatif tentang apa yang akan terjadi jika tidak mampu menyelesaikan tes; (3) reaksi fisik, seperti gugup, keringat dingin ketika menyelesaikan tes; (4) mempunyai hambatan dalam memikirkan butir tes atau mengingat materi yang telah dibaca sebelumnya; (5) kuatir bahwa siswa lainnya akan mencapai skor yang lebih tinggi; dan (6) kuatir tentang tes akan mengurangi kematangan seperti yang telah dimiliki. Gejalagejala ini dapat mempengaruhi mental yang dapat menghambat proses berpikir dan konsentrasi siswa.

Untuk mengatasi efek negatif dari kecemasan tes yang dirasakan siswa, perlu adanya upaya stabilisasi kecemasan tes. Dalam hal ini, stabilisasi kecemasan tes yang dimaksudkan tidak berarti menghilangkan sama sekali kecemasan tes siswa, tetapi memberikan perlakuan sedemikian rupa sehingga tetap stabil pada tingkat kecemasan menengah atau kecemasan normal (White, 2004). Di mana menurut penganut Teori Perilaku, perlakukan terhadap kecemasan tes dapat diberikan secara langsung melalui pembelajaran di kelas (Miller,et al., 1990). Pembelajaran yang dimaksud menurut Hopkins dan Antes (1990) adalah berhubungan dengan persiapan siswa secara akademik dan secara emosional untuk menyelesaikan tes disertai dengan aktivitas untuk membantu siswa membangun rasa percaya diri, menumbuhkan kesadaran akan kemampuannya, dan menimbulkan optomisme untuk mencapai tujuannya.

Juga dijelaskan bahwa para guru dapat membantu menyediakan lingkungan yang memungkinkan siswa merasa 
senang, dengan mengajarkan teknik stabilisasi kecemasan tes dan membantu siswa mengembangkan sikap positif terhadap tes dan terhadap diri sendiri, dengan melakukan beberapa hal, yakni: (1) membantu siswa untuk percaya diri sebagai orang yang harus belajar; (2) membantu mengembangkan sikap yang benar terhadap tes dengan cara menngarahkan siswa untuk menanggapi tes sebagai aktivitas yang biasa dilakukan di sekolah; dan (3) membantu siswa untuk mengembangkan kemampuan dalam menyelesaikan tes; dan 4) berhubungan dengan orang tua siswa untuk menyampaikan peranan mereka dalam mengontrol persiapan anak-anak mereka sebelum pelaksanaan tes (Hopkins dan Antes, 1990).

Kecemasan tes siswa yang terlalu tinggi atau terlalu rendah merupakan masalah bagi guru. Untuk itu, menurut Bugelski seperti dikutip Lindgren (1980) bahwa pemberian perhatian merupakan dasar bagi semua bentuk pemecahan masalah kecemasan tes. Perhatian yang dimaksud dapat dilakukan dalam bentuk dorongan, penguatan, penghindaran hukuman, pengembangan rasa ingin tahu siswa, dan atau yang lainnya. Dasar pemberian perhatian tersebut adalah kecemasan tes. Tugas guru dalam hal ini adalah membentuk tingkat kecemasan tes yang wajar. Jelasnya, bimbingan stabilisasi kecemasan tes adalah pembelajaran dan latihan tentang tata cara menanggulangi kecemasan tes, yang mencakup persiapan mental, teknik relaksasi, cara mengatasi ketegangan, dan persiapan secara fisik baik sebelum, sedang dan setelah pelaksanaan tes guna meningkatkan kemampuan siswa dalam menjawab tes.

\section{Ketimpangan Skor Tes Akuntansi}

Ketimpangan pengukuran terjadi apabila tes gagal mengukur secara wajar karakteristik siswa yang hendak diukurnya kendatipun tes tersebut merupakan ukuran yang paling cocok untuk siswa. Menurut Hulin, Drasgow, dan Parsons (1983), pembahasan tentang ketimpangan pengukuran hanya terbatas 
pada keanehan pola jawaban siswa dalam tes, ada jawaban yang benar terhadap butir-butir tes yang sukar dan ada jawaban salah terhadap butir-butir tes yang mudah. Pola jawaban yang dihasilkan oleh peserta tes kadang-kadang tidak normal. Ada sejumlah jawaban benar terhadap butir-butir sulit pada seperdua tes yang pertama dan ada sejumlah jawaban salah terhadap butir-butir tes yang mudah pada seperdua tes berikutnya, atau peserta tes yang kreatif mungkin memberikan penafsiran yang berbeda terhadap beberapa butir tes yang mudah, akibatnya, pola jawaban siswa terhadap butir seperti ini tidak akan cocok dengan model teori respons butir (item response theory) yang mengasumsikan peluang jawaban benar adalah fungsi dari kecerdasan peserta tes. Jadi dalam hal ini tidak ada bias atau juga tidak ada keanehan yang terjadi secara sistematis bagi individu atau subpopulasi, sebab keanehan ini mungkin tidak stabil dan tidak dibahas dalam prosedur analisis butir.

Ketimpangan pengukuran bersumber dari atmosfir dan kondisi penilaian. Dijelaskan oleh Nitko (1996), Wiersma dan Jurs (1990) bahwa tekanan mental peserta tes, seperti perasaan cemas, khawatir, takut akan gagal, kekurangmampuan dalam menulis, dan perasaan tidak disukai, menyebabkan peserta tes tidak berhasil menjawab benar butir-butir tes. Sebagai akibatnya siswa-siswa seperti ini akan memperoleh skor yang tidak tepat, yakni tidak sesuai dengan kemampu-an mereka yang sebenarnya.

Berdasarkan uraian di atas dapat disimpulkan bahwa ketimpangan skor tes Akuntansi muncul apabila butir-butir tes gagal mengukur secara tepat karakteristik siswa yang hendak diukurnya kendatipun tes tersebut merupakan ukuran yang cocok untuk siswa secara keseluruhan. Atau dengan kata lain, ketimpangan skor tes menyebabkan seseorang siswa memperoleh skor yang tidak sesuai dengan kemampuannya, mungkin lebih rendah atau mungkin pula lebih tinggi dari yang seharusnya dicapai. 


\section{HIPOTESIS PENELITIAN}

Hipotesis yang diuji dalam penelitian adalah: (1) Secara keseluruhan, ketimpangan skor tes Akuntansi siswa yang memperoleh bimbingan kiat dalam menjawab tes lebih tinggi dari siswa yang memperoleh bimbingan stabilisasi kecemasan tes; (2) Secara keseluruhan, ketimpangan skor tes Akuntansi siswa yang memiliki kecemasan tes tinggi lebih tinggi dari siswa yang memiliki kecemasan tes rendah dan sedang; (3) Pada pemberian bimbingan kiat dalam menjawab tes, ketimpangan skor tes Akuntansi siswa yang memiliki kecemasan tes tinggi lebih tinggi dari siswa yang memiliki kecemasan tes rendah dan sedang; (4) Pada pemberian bimbingan stabilisasi kecamasan tes, ketimpangan skor tes Akuntansi siswa yang memiliki kecemasan tes tinggi lebih tinggi dari siswa yang memiliki kecemasan tes sedang dan rendah; (5) Bagi siswa yang memiliki kecemasan tes tinggi, ketimpangan skor tes Akuntansi siswa yang memperoleh bimbingan kiat dalam menjawab tes lebih tinggi dari siswa yang memperoleh bimbingan stabilisasi kecemasan tes; (6) Bagi siswa yang memiliki kecemasan tes sedang, ketimpangan skor tes Akuntansi siswa yang memperoleh bimbingan kiat dalam menjawab tes lebih rendah dari siswa yang memperoleh bimbingan stabilisasi kecemasan tes; (7) Bagi siswa yang memiliki kecemasan tes rendah, ketimpangan skor tes Akuntansi siswa yang memperoleh bimbingan kiat dalam menjawab tes lebih tinggi dari siswa yang memperoleh bimbingan stabilisasi kecemasan tes; dan (8) Terdapat pengaruh interaksi antara bimbingan tes dengan kecemasan tes terhadap ketimpangan skor tes Akuntansi siswa.

\section{E. METODOLOGI PENELITIAN}

Dalam penelitian digunakan rancangan eksperimen faktorial 2x3, dengan melibatkan variabel terikat yaitu ketimpangan skor tes Akuntansi, serta variabel bebas yaitu bimbingan tes sebagai variabel perlakuan dan kecemasan tes sebagai variabel kontrol. Variabel perlakuan terdiri atas dua level yaitu: bimbingan kiat dalam menjawab tes dan bimbingan stabilisasi kecemasan tes. Sedangkan variabel kontrolnya terdiri atas tiga level, yaitu: 
kecemasan tes tinggi, sedang, dan rendah. Rancangan penelitian ini dapat digambarkan sebagai berikut:

\section{Rancangan Faktorial $2 \times 3$}

\begin{tabular}{|l|c|c|c|}
\hline \multirow{2}{*}{$\begin{array}{c}\text { Kecemasan } \\
\text { Tes (B) }\end{array}$} & \multicolumn{2}{|c|}{ Bimbingan Tes (A) } & \multirow{2}{*}{ Total } \\
\cline { 2 - 3 } & $\begin{array}{c}\text { Kiat dalam Menjawab } \\
\text { Tes (A1) }\end{array}$ & $\begin{array}{c}\text { Stabilisasi Kecemasan } \\
\text { Tes (A2) }\end{array}$ & \\
\hline Tinggi (B1) & A1B1 & A2B1 & B1 \\
\hline Sedang (B2) & A1B2 & A2B2 & B2 \\
\hline Rendah (B3) & A1B3 & A2B3 & B3 \\
\hline Total & A1 & A2 & \\
\hline
\end{tabular}

Penelitian dilaksanakan pada siswa-siswi kelas 1 SMU Negeri 15 dan SMU Negeri 18. Pemilihan kedua sekolah tersebut dilakukan secara acak. Jumlah sampel terdiri dari 200 siswa dipilih secara acak pada masing-masing sekolah perlakuan. Data penelitian terdiri atas ketimpangan skor tes Akuntansi dan kecemasan tes siswa. Ketimpangan skor tes Akuntansi diperoleh dengan menggunakan tes Akuntansi yang dikembangkan oleh peneliti (koefisien reliabilitas tes $=0,90)$. Data kecemasan tes siswa diperoleh dengan menggunakan instrumen kecemasan tes (koefisien reliabilitas instrumen $=0,89$ ). Alat-alat analisis yang digunakan untuk menguji hipotesis penelitian adalah: ketimpangan skor tes Akuntansi dihitung dengan menggunakan metode korelasi biserial skor peserta dari Donlon dan Fischer (Hulin, Drasgow, dan Parsons, 1983). Hipotesis penelitian diuji dengan menggunakan analisis varians yang dilanjutkan dengan uji Sheffe jika terdapat perbedaan yang signifikan antara kelompok-kelompok data yang diperbandingkan (Ferguson dan Takane, 989). Uji persyaratan analisis menggunakan uji Lilliefors untuk menguji normalitas data dan uji Barlett untuk menguji homogenitas varians data (Sujana, 1996). 


\section{F. HASIL PENELITIAN DAN PEMBAHASAN}

1. Hasil Penelitian

Deskripsi data ketimpangan skor tes Akuntansi

\begin{tabular}{|c|c|c|c|c|}
\hline \multirow{2}{*}{\multicolumn{2}{|c|}{ Sumber statistik }} & \multicolumn{2}{|c|}{ A } & \multirow{2}{*}{$\Sigma \mathrm{B}$} \\
\hline & & A1 & A2 & \\
\hline B1 & $\begin{array}{l}N \\
\bar{X} \\
\mathrm{~s}\end{array}$ & $\begin{array}{l}27 \\
32,090 \\
13,026\end{array}$ & $\begin{array}{l}27 \\
48,558 \\
17,021\end{array}$ & $\begin{array}{l}54 \\
40,324 \\
17,159\end{array}$ \\
\hline B2 & $\begin{array}{l}N \\
\bar{X} \\
\mathrm{~S}\end{array}$ & $\begin{array}{l}46 \\
65,547 \\
10,395\end{array}$ & $\begin{array}{l}46 \\
58,893 \\
13,907\end{array}$ & $\begin{array}{l}92 \\
62,220 \\
12,659\end{array}$ \\
\hline B3 & $\begin{array}{l}N \\
\bar{X} \\
\mathrm{~s}\end{array}$ & $\begin{array}{l}27 \\
44,904 \\
10,577\end{array}$ & $\begin{array}{l}27 \\
67,264 \\
12,533\end{array}$ & $\begin{array}{l}54 \\
56,084 \\
16,102\end{array}$ \\
\hline$\Sigma \mathrm{A}$ & $\begin{array}{l}N \\
\bar{X} \\
\mathrm{~s}\end{array}$ & $\begin{array}{l}100 \\
50,940 \\
8,140\end{array}$ & $\begin{array}{l}100 \\
58,363 \\
15,912\end{array}$ & $\begin{array}{l}200 \\
54,651 \\
17,421\end{array}$ \\
\hline
\end{tabular}

Hasil pengujian persyaratan analisis data menunjukkan bahwa kelompok-kelompok data dalam penelitian berasal dari populasi yang berdistribusi normal dan memiliki varians yang homogen. Dari hasil analisis varians dua jalur diperoleh dua pengaruh utama (main effect) antar kolom sebagai variabel perlakuan dan pengaruh utama antar baris sebagai variabel kontrol, serta pengaruh interaksi antar kolom dan baris. Hasil-hasil pengujian hipotesis dapat dirangkum dalam tabel berikut: 
Tabel hasil analisis varians

\begin{tabular}{|l|c|r|c|c|c|c|}
\hline \multirow{2}{*}{ Sumber Varians } & \multicolumn{1}{|c|}{$\mathrm{JK}$} & $\mathrm{db}$ & \multirow{2}{*}{$\mathrm{RJK}$} & \multirow{2}{*}{$\mathrm{F}_{\mathrm{h}}$} & \multicolumn{2}{|c|}{$\mathrm{F}_{\mathrm{t}}$} \\
\cline { 6 - 8 } & & & & & 0,05 & 0,01 \\
\hline Antar Kolom & 2754,7644 & 1 & 2754,764 & $16,443^{* *}$ & 3,94 & 6,90 \\
Antar Baris & 16466,004 & 2 & 8233,002 & $49,143^{* *}$ & 3,09 & 4,82 \\
Interaksi & 8674,6815 & 2 & 4337,341 & $25,889^{* *}$ & 3,09 & 4,82 \\
\hline Antar Kelompok & 27895,450 & 5 & -- & & & \\
\hline Dalam kelompol & 32501,422 & 194 & 167,533 & & -- & -- \\
\hline Total direduksi & 60396,872 & 199 & & & & \\
Rerata & 597355,323 & 1 & -- & -- & -- & -- \\
\hline Total & 657752,195 & 200 & & & & \\
\hline
\end{tabular}

** $p<0,01$

\section{Pembahasan}

Hasil analisis pengaruh utama antara kolom memberikan nilai $\mathrm{F}_{\text {hitung }}=16,443>\mathrm{F}_{\text {tabel(á=0,01)(db=1;194) }}=6,90$. Dengan demikian maka terdapat perbedaan yang sangat signifikan antara ketimpangan skor tes Akuntansi siswa yang memperoleh bimbingan kiat dalam menjawab tes dengan ketimpangan skor tes Akuntansi siswa yang memperoleh bimbingan stabilisasi kecemasan tes. Selanjutnya, hasil perbandingan ketimpangan skor tes Akuntansi kelompok siswa yang memperoleh bimbingan kiat dalam menjawab tes (A1) dengan ketimpangan skor tes Akuntansi kelompok siswa yang memperoleh bimbingan stabilisasi kecemasan tes (A2) diperoleh selisih rerata 7,423 dan $F_{\text {hitung }}=16,445>F_{(a ́=0,05)(d b=1 ; 198)}=3,890$. Dengan demikian, maka ketimpangan skor tes Akuntansi siswa kelompok A1 lebih tinggi dari ketimpangan skor tes Akuntansi siswa kelompok A2. Yang berarti menolak hipotesis nol dan menerima hipotesis alternatif yang menyatakan: "Secara keseluruhan, ketimpangan skor tes Akuntansi siswa yang memperoleh bimbingan kiat dalam menjawab tes lebih tinggi dari siswa yang memperoleh bimbingan stabilisasi kecemasan tes." 
Hasil analisis pengaruh utama antara baris memberikan nilai $\mathrm{F}_{\text {hitung }}=49,143>\mathrm{F}_{\text {tabel(á }=0,01)(\mathrm{db}=2 ; 194)}=4,82$. Dengan demikian, maka terdapat perbedaan yang sangat signifikan antara ketimpangan skor tes Akuntansi siswa yang memiliki kecemasan tes tinggi, sedang, dan rendah. Hasil perbandingan ketimpangan skor tes Akuntansi kelompok siswa yang memiliki kecemasan tes tinggi (B1) dan ketimpangan skor tes Akuntansi kelompok siswa yang memiliki kecemasan tes sedang (B2) diperoleh selisih rerata sebesar 21,896 dan $F_{\text {hitung }}=48,692>$ $\mathrm{F}_{(\dot{a}=0,05)(\mathrm{db}=2 ; 143)}=3,060$; yang berarti ketimpangan skor tes Akuntansi siswa yang memiliki kecemasan tes tinggi lebih tinggi dari ketimpangan skor tes Akuntansi siswa yang memiliki kecemasan tes sedang. Hasil perbandingan ketimpangan skor tes Akuntansi kelompok siswa yang memiliki kecemasan tes tinggi (B1) dengan ketimpangan skor tes Akuntansi kelompok siswa yang memiliki kecemasan tes rendah (B3) diperoleh selisih rerata 15,760 dan $\mathrm{F}_{\text {hitung }}=20,015>\mathrm{F}_{(\dot{a}=0,05)(\mathrm{db}=2 ; 105)}=$ 3,060. Dengan demikian, maka ketimpangan skor tes Akuntansi siswa yang memiliki kecemasan tes tinggi lebih tinggi dari ketimpangan skor tes Akuntansi siswa yang memiliki kecemasan tes rendah. Dari perbandingan ketimpangan skor tes Akuntansi kelompok siswa yang memiliki kecemasan tes sedang (B2) dengan ketimpangan skor tes Akuntansi kelompok siswa yang memiliki kecemasan tes rendah (B3) diperoleh selisih rerata sebesar 6,136 dan $F_{\text {hitung }}=3,854>F_{(a ́=0,05)(d b=}$ $2 ; 143)=3,060$. Dengan demikian, maka ketimpangan skor tes Akuntansi siswa yang memiliki kecemasan tes sedang lebih rendah dari ketimpangan skor tes Akuntansi siswa yang memiliki kecemasan tes rendah. Hasil-hasil pengujian ini menunjukkan bahwa ketimpangan skor tes Akuntansi siswa yang memiliki kecemasan tes tinggi lebih tinggi dari ketimpangan skor tes Akuntansi siswa yang memiliki kecemasan tes rendah dan ketimpangan skor tes Akuntansi siswa yang memiliki kecemasan tes rendah lebih tinggi dari ketimpangan skor tes Akuntansi siswa yang memiliki kecemasan tes sedang. Jadi dalam hal ini ketimpangan skor 
tes Akuntansi yang paling rendah dicapai oleh siswa yang memiliki kecemasan tes sedang, dan ketimpangan skor tes Akuntansi yang paling tinggi dicapai oleh siswa yang memiliki kecemasan tes tinggi. Dengan demikian maka menolak hipotesis nol dan menerima hipotesis alternatif yang menyatakan: "Secara keseluruhan, ketimpangan skor tes Akuntansi siswa yang memiliki kecemasan tes tinggi lebih tinggi dari siswa yang memiliki kecemasan tes rendah dan sedang."

Melalui perbandingan ketimpangan skor tes Akuntansi kelompok siswa yang memiliki kecemasan tes tinggi yang memperoleh bimbingan kiat dalam menjawab tes (A1B1) dengan ketimpangan skor tes Akuntansi kelompok siswa yang memiliki kecemasan tes sedang yang memperoleh bimbingan kiat dalam menjawab tes (A1B2) diperoleh selisih rerata 33,457 dan $F_{\text {hitung }}=56,838>F_{(a ́=0,05)(d b=2 ; 70)}=3,130$. Hal ini berarti ketimpangan skor tes Akuntansi siswa kelompok A1B1 lebih tinggi dari ketimpangan skor tes Akuntansi siswa kelompok A1B2. Melalui perbandingan ketimpangan skor tes Akuntansi kelompok siswa yang memiliki kecemasan tes tinggi yang memperoleh bimbingan kiat dalam menjawab tes (A1B1) dengan ketimpangan skor tes Akuntansi kelompok siswa yang memiliki kecemasan tes rendah yang memperoleh bimbingan kiat dalam menjawab tes (A1B3) diperoleh selisih rerata 12,814 dan $\mathrm{F}_{\text {hitung }}=6,616>\mathrm{F}_{(\dot{a}=0,05)(\mathrm{db}=2 ; 51)}=3,180$. Hal ini berarti ketimpangan skor tes Akuntansi siswa kelompok A1B1 lebih tinggi dari ketimpangan skor tes Akuntansi siswa kelompok A1B3. Dari perbandingan ketimpangan skor tes Akuntansi kelompok siswa yang memiliki kecemasan tes sedang yang memperoleh bimbingan kiat dalam menjawab tes (A1B2) dengan ketimpangan skor tes Akuntansi kelompok siswa yang memiliki kecemasan tes rendah yang memperoleh bimbingan kiat dalam menjawab tes (A1B3) diperoleh selisih rerata 20,643 dan $\mathrm{F}_{\text {hitung }}=21,638>\mathrm{F}_{(\mathrm{a}=0,05)(\mathrm{db}=2 ; 70)}=3,130$. Hal ini berarti ketimpangan skor tes Akuntansi siswa kelompok A1B2 lebih rendah dari ketimpangan skor tes Akuntansi siswa kelompok 
A1B3. Hasil-hasil perbandingan tersebut menunjukkan bahwa pada pemberian bimbingan kiat dalam menjawab tes ketimpangan skor tes Akuntansi kelompok siswa yang memiliki kecemasan tes tinggi (A1B1) lebih tinggi dari ketimpangan skor tes Akuntansi kelompok siswa yang memiliki kecemasan tes rendah (A1B3) dan lebih tinggi pula dari ketimpangan skor tes Akuntansi kelompok siswa yang memiliki kecemasan tes sedang (A1B2). Selanjutnya, pada pemberian bimbingan tes yang sama, ketimpangan skor tes Akuntansi kelompok siswa yang memiliki kecemasan tes sedang (A1B2) lebih rendah dari ketimpangan skor tes Akuntansi kelompok siswa yang memiliki kecemasan tes rendah (A1B3). Jadi, pada pemberian bimbingan kiat dalam menjawab tes ketimpangan skor tes Akuntansi yang paling tinggi dicapai oleh siswa yang memiliki kecemasan tes tinggi, sedangkan ketimpangan skor tes Akuntansi yang paling rendah dicapai siswa yang memiliki kecemasan tes sedang. Dengan demikian maka menolak hipotesis nol dan menerima hipotesis alternatif yang menyatakan: "Pada pemberian bimbingan kiat dalam menjawab tes, ketimpangan skor tes Akuntansi siswa yang memiliki kecemasan tes tinggi lebih tinggi dari siswa yang memiliki kecemasan tes rendah dan sedang."

Dari perbandingan ketimpangan skor tes Akuntansi kelompok siswa yang memiliki kecemasan tes tinggi yang memperoleh bimbingan stabilisasi kecemasan tes (A2B1) dengan ketimpangan skor tes Akuntansi kelompok siswa yang memiliki kecemasan tes sedang yang memperoleh bimbingan stabilisasi kecemasan tes (A2B2) diperoleh selisih rerata 10,305 dan $\mathrm{F}_{\text {hitung }}$ $=5,424>F_{(a=0,05)(d b=2 ; 70)}=3,130$. Hal ini berarti ketimpangan skor tes Akuntansi siswa kelompok A2B1 lebih tinggi dari ketimpangan skor tes Akuntansi siswa kelompok A2B2. Dari perbandingan ketimpangan skor tes Akuntansi kelompok siswa yang memiliki kecemasan tes tinggi yang memperoleh bimbingan stabilisasi kecemasan tes (A2B1) dengan ketimpangan skor tes Akuntansi kelompok siswa yang memiliki 
kecemasan tes rendah yang memperoleh bimbingan stabilisasi kecemasan tes (A2B3) diperoleh selisih rerata 18,706 dan $F_{\text {hitung }}$ $=14,098>F_{(a=0,05)(d b=2 ; 51)}=3,180$. Hal ini berarti ketimpangan skor tes Akuntansi siswa kelompok A2B1 lebih tinggi dari ketimpangan skor tes Akuntansi siswa kelompok A2B3. Dari perbandingan ketimpangan skor tes Akuntansi kelompok siswa yang memiliki kecemasan tes sedang dan memperoleh bimbingan stabilisasi kecemasan tes (A2B2) dengan ketimpangan skor tes Akuntansi kelompok siswa yang memiliki kecemasan tes rendah yang memperoleh bimbingan stabilisasi kecemasan tes (A2B3) diperoleh selisih rerata 8,371 dan $F_{\text {hitung }}=3,558>F_{(a ́=0,05)(d b=2 ; 70)}=3,130$. Hal ini berarti ketimpangan skor tes Akuntansi siswa kelompok A2B2 lebih tinggi dari ketimpangan skor tes Akuntansi siswa kelompok A2B3. Hasilhasil pengujian ini menunjukkan bahwa pada pemberian bimbingan stabilisasi kecemasan tes, ketimpangan skor tes Akuntansi kelompok siswa yang memiliki kecemasan tes tinggi lebih tinggi dari ketimpangan skor tes Akuntansi kelompok siswa yang memiliki kecemasan tes sedang dan lebih tinggi pula dari ketimpangan skor tes Akuntansi kelompok siswa yang memiliki kecemasan tes rendah. Selanjutnya, pada pemberian bimbingan tes yang sama, ketimpangan skor tes Akuntansi kelompok siswa yang memiliki kecemasan tes sedang lebih tinggi dari ketimpangan skor tes Akuntansi kelompok siswa yang memiliki kecemasan tes rendah. Jadi, pada pemberian bimbingan stabilisasi kecemasan tes ketimpangan skor tes Akuntansi yang paling tinggi dicapai oleh siswa yang memiliki kecemasan tes tinggi, sedangkan ketimpangan skor tes Akuntansi yang paling rendah dicapai siswa yang memiliki kecemasan tes rendah. Hal ini berarti menolak hipotesis nol dan menerima hipotesis alternatif yang menyatakan bahwa "Pada pemberian bimbingan stabilisasi kecemasan tes, ketimpangan skor tes Akuntansi siswa yang memiliki kecemasan tes tinggi lebih tinggi dari siswa yang memiliki kecemasan tes sedang dan rendah." 
Dari perbandingan ketimpangan skor tes Akuntansi kelompok siswa yang memiliki kecemasan tes tinggi yang memperoleh bimbingan kiat dalam menjawab tes (A1B1) dengan ketimpangan skor tes Akuntansi kelompok siswa yang memiliki kecemasan tes tinggi yang memperoleh bimbingan stabilisasi kecemasan tes (A2B1) diperoleh selisih rerata 16,468 dan $\mathrm{F}_{\text {hitung }}$ $=21,853>F_{(a ́=0,05)(d b=1 ; 52)}=4,030$. Dengan demikian maka ketimpangan skor tes Akuntansi siswa kelompok A1B1 lebih tinggi dari ketimpangan skor tes Akuntansi siswa kelompok A2B1. Yang berarti menolak hipotesis nol dan menerima hipotesis alternatif yang menyatakan "Pada kecemasan tes tinggi, ketimpangan skor tes Akuntansi siswa yang memperoleh bimbingan kiat dalam menjawab tes lebih tinggi dari siswa yang memperoleh bimbingan stabilisasi kecemasan tes."

Dari perbandingan ketimpangan skor tes Akuntansi kelompok siswa yang memiliki kecemasan tes sedang yang memperoleh bimbingan kiat dalam menjawab tes (A1B2) dengan ketimpangan skor tes Akuntansi kelompok siswa yang memiliki kecemasan tes sedang yang memperoleh bimbingan stabilisasi kecemasan tes (A2B1) diperoleh selisih rerata 6,654 dan $F_{\text {hitung }}$ $=6,078>F_{(a=0,05)(d b=1 ; 90)}=3,910$. Dengan demikian maka ketimpangan skor tes Akuntansi siswa kelompok A1B2 lebih rendah dari ketimpangan skor tes Akuntansi siswa kelompok A2B2. Yang berarti menolak hipotesis nol dan menerima hipotesis alternatif yang menyatakan "Pada kecemasan tes sedang, ketimpangan skor tes Akuntansi siswa memperoleh bimbingan kiat dalam menjawab tes lebih rendah dari siswa yang memperoleh bimbingan stabilisasi kecemasan tes."

Dari perbandingan ketimpangan skor tes Akuntansi kelompok siswa yang memiliki kecemasan tes rendah yang memperoleh bimbingan kiat dalam menjawab tes (A1B3) dengan ketimpangan skor tes Akuntansi kelompok siswa yang memiliki kecemasan tes rendah yang memperoleh bimbingan stabilisasi kecemasan tes (A2B3) diperoleh selisih rerata 22,360 dan $F_{\text {hitung }}$ 
$=40,288>F_{(a ́=0,05)(d b=1 ; 52)}=4,030$. Dengan demikian maka ketimpangan skor tes Akuntansi siswa kelompok A1B3 lebih tinggi dari ketimpangan skor tes Akuntansi siswa kelompok A2B3. Yang berarti menolak hipotesis nol dan menerima hipotesis alternatif yang menyatakan "Pada kecemasan tes rendah, ketimpangan skor tes Akuntansi siswa yang memperoleh bimbingan kiat dalam menjawab tes lebih tinggi dari siswa yang memperoleh bimbingan stabilisasi kecemasan tes."

Hasil pengujian pengaruh interaksi antara bimbingan tes dengan kecemasan tes terhadap ketimpangan skor tes Akuntansi memberikan nilai $\mathrm{F}_{\text {hitung }}=25,889>\mathrm{F}_{\text {tabel( }(0,05 ; 2 / 194)}=$ 4,82 . Hal ini berarti menolak hipotesis nol. Dengan demikian maka: "Terdapat pengaruh interaksi antara bimbingan tes dengan kecemasan tes terhadap ketimpangan skor tes Akuntansi siswa."

\section{G. SIMPULAN DAN SARAN}

\section{Simpulan}

Pertama, ketimpangan skor tes Akuntansi siswa yang memperoleh bimbingan kiat dalam menjawab tes lebih tinggi dari siswa yang memperoleh bimbingan stabilisasi kecemasan tes. Hal ini berarti bimbingan stabilisasi kecemasan tes lebih efektif untuk mengatasi ketimpangan skor tes Akuntansi siswa dibanding dengan bimbingan kiat dalam menjawab tes

Kedua, ketimpangan skor tes Akuntansi siswa yang memiliki kecemasan tes tinggi lebih tinggi dari siswa yang memiliki kecemasan tes rendah dan sedang. Dalam hal ini ketimpangan skor tes Akuntansi yang paling tinggi dicapai oleh siswa yang memiliki kecemasan tes tinggi, dan ketimpangan skor tes Akuntansi yang paling rendah dicapai oleh siswa yang memiliki kecemasan tes sedang. 
Ketiga, pada pemberian bimbingan kiat dalam menjawab tes, ketimpangan skor tes Akuntansi siswa yang memiliki kecemasan tes tinggi lebih tinggi dari siswa yang memiliki kecemasan tes rendah dan sedang. Berarti, melalui pemberian bimbingan kiat dalam menjawab tes ketimpangan skor tes Akuntansi yang paling tinggi dicapai oleh siswa yang memiliki kecemasan tes tinggi dan ketimpangan skor tes Akuntansi yang paling rendah dicapai oleh siswa yang memiliki kecemasan tes sedang. Dengan demikian maka bimbingan kiat dalam menjawab tes efektif untuk mengatasi ketimpangan skor tes Akuntansi siswa yang memiliki kecemasan tes sedang, namun kurang efektif untuk mengatasi ketimpangan skor tes Akuntansi siswa yang memiliki kecemasan tes rendah dan tinggi.

Keempat, pada pemberian bimbingan stabilisasi kecemasan tes, ketimpangan skor tes Akuntansi siswa yang memiliki kecemasan tes tinggi lebih tinggi dari siswa yang memiliki kecemasan tes sedang dan rendah. Berarti, melalui pemberian bimbingan stabilisasi kecemasan tes, ketimpangan skor tes Akuntansi yang paling tinggi dicapai oleh siswa yang memiliki kecemasan tes tinggi dan ketimpangan skor tes Akuntansi yang paling rendah dicapai oleh siswa yang memiliki kecemasan tes rendah. Dengan demikian maka bimbingan stabilisasi kecemasan tes efektif untuk mengatasi ketimpangan skor tes Akuntansi siswa yang memiliki kecemasan rendah namun kurang efektif untuk mengatasi ketimpangan skor tes Akuntansi siswa yang memiliki kecemasan tes tinggi dan sedang.

Kelima, pada kecemasan tes tinggi, ketimpangan skor tes Akuntansi siswa yang memperoleh bimbingan kiat dalam menjawab tes lebih tinggi dari siswa yang memperoleh bimbingan stabilisasi kecemasan tes. Berarti bimbingan tes yang lebih efektif untuk mengatasi ketimpangan skor tes Akuntansi siswa yang memiliki kecemasan tes tinggi adalah bimbingan stabilisasi kecemasan tes. 
Keenam, pada kecemasan tes sedang, ketimpangan skor tes Akuntansi siswa yang memperoleh bimbingan kiat dalam menjawab tes lebih rendah dari siswa yang memperoleh bimbingan stabilisasi kecemasan tes. Berarti, bagi siswa-siswa yang memiliki kecemasan tes sedang pemberian bimbingan kiat dalam menjawab tes lebih efektif untuk mengatasi ketimpangan skor tes Akuntansi siswa dibanding dengan pemberian bimbingan stabilisasi kecemasan tes.

Ketujuh, pada kecemasan tes rendah, ketimpangan skor tes Akuntansi siswa yang memperoleh bimbingan kiat dalam menjawab tes lebih tinggi dari siswa yang memperoleh bimbingan stabilisasi kecemasan tes. Hal ini berarti bimbingan stabilisasi kecemasan tes lebih efektif untuk mengatasi ketimpangan skor tes Akuntansi siswa yang memiliki kecemasan tes rendah dibanding dengan pemberian bimbingan kiat dalam menjawab tes.

Kedelapan, terdapat pengaruh interaksi antara bimbingan tes dengan kecemasan tes terhadap ketimpangan skor tes Akuntansi. Terjadinya interaksi tersebut disebabkan oleh perbedaan pengaruh masing-masing jenis bimbingan tes terhadap kecemasan tes siswa. Bimbingan kiat dalam menjawab tes efektif untuk mengatasi ketimpangan skor tes Akuntansi siswa yang memiliki kecemasan tes sedang. Sedangkan bimbingan stabilisasi kecemasan tes efektif untuk mengatasi ketimpangan skor tes Akuntansi siswa yang memiliki kecemasan tes rendah.

\section{Saran}

Pertama, pengaruh kiat dalam menjawab tes sebagai suatu sumber perbedaan tambahan perlu diperkecil atau dihapuskan. Jika memungkinkan pengajaran kiat dalam menjawab tes perlu dimasukkan dalam kurikulum sejak di perguruan tinggi atau perlu diberikan pelatihan khusus kepada para pengajar atau 
calon pengajar, agar mereka menyadari manfaat kiat dalam menjawab tes bagi siswa dan agar tidak memberi peluang bagi siswa yang memahami kiat dalam menjawab tes untuk memanfaatkan kelemahan guru dalam mengembangkan tes.

Kedua, guru dapat membangun sikap mental positif siswa terhadap tes dengan menjelaskan mengapa tes itu penting dan memberitahukan lebih awal waktu pelaksanaan tes. Guru dapat mengurangi kecemasan tes siswa dengan membantu mereka untuk meningkatkan kemampuan dalam menanggapi tes. .

Ketiga, pada dasarnya, tes hasil belajar mengukur dua jenis pengetahuan, yaitu pengetahuan tentang sasaran ukur tes dan pengetahuan tentang kiat dalam menjawab tes. Untuk itu diharapkan kepada para pendidik untuk mengintegrasikan materi pelajaran yang diajarkannya dengan keahlian atau kiat dalam menjawab tes dalam pembelajaran di kelas.

Keempat, penggunaan hasil tes dalam pengambilan keputusan tentang siswa harus dilakukan dengan hati-hati, sebab hasil tes tidak selalu menggambarkan kemampuan siswa yang sebenarnya. Untuk itu, jika hasil tes akan digunakan dalam pengambilan keputusan, maka sebaiknya dilengkapi dengan informasi tambahan yang diperoleh dari sumber-sumber lainnya, misalnya partisipasi siswa dalam proses pembelajaran.

\section{DAFTAR PUSTAKA}

Barrier, Helen et al. (2004). The Test-Taking Strategy. http://www.mxctc.edu/ clc/testp rep.htm.

Brown, Frederick G. 1983. Principles of Educational and Psychological Testing. New York: Hotl, Rinehart and Winston.

Ebel, Robert L. (1979). Essentials of Educational Measurement. New Jersey: Prentice-Hall Inc., Englewood Cliffs.

Ferguson, George A. and Yoshio Takane. 1989. Statistical Analysis In Psycohology and Education. New York: McGrow-Hill Book Company.

Gay, L.R. (1992). Educational Research Competencies for Analysis and 
Application. Singapore: Macmillan Publishing Company.

Gronlund, Norman E. (1985). Measurement and Evaluation in Teaching. New York: McMillan Publishing Company.

Haniza. (2003). Test-wiseness: Is it good or Bad? http://www.wsu.edu,/ dwong/ CEP900/ Haniza-Test-wiseness.rtf.

Hopkins, Charles D. and Richard L. Antes. 1990. Classroom Measurement and Evaluation. Itasca, Illinois: F.E. Peacock Publishers, Inc.

Horngren, Charles T., Gary L. Sundem, and John A. Elliott. (1996). Introduction to Finantial Accounting. New Jersey: Prentice-Hall International, Inc.

Hulin, Charles L. Fritz Drasgow, and Charles K. Parsons. (1983). Item Response Theory: Applications to Psychological Measurement. Illinois: Dow JonesIrwin.

Lindgren, Hendry Clay. (1980). Educational Psychology in the Classroom. New York: Oxford University Press.

Linn, Robert L. (Ed.). (1989). Educational Measurement. New York: Macmillan Publishing Company.

Miller, William R. Carolina E. Yahne, and John M. Rhodes. (1990). Adjustment: The Psychology of Change. Englewood Cliffs, New Jersey: Prentice-Hall. Naga, Dali S. (1992). Pengantar Teori Sekor pada Pengukuran Pendidikan. Jakarta: Gunadarma.

Nitko, Anthony J. (1996). Educational Assessment of Students. New Jersey: Prentice-Hall, Inc.

Oosterhof, Albert. (1999). Developing and Using Classroom Assessment. New Jersey: Prentice-Hall.

Sarason, Seymour B. et al. (1960). Anxiety in Elementary School Children. Yale University: John Wiley \& Sons.

Sujana. (1986). Metode Statistika. Bandung: Tarsito.

Sweetnam, Kris R. (2004). Test Taking Strategy and Student Achievement. http://www. ksweetna/doquet.k12/ mn.us.htm.

Vattanapath, Ratana and Kornpak Jaiprayoon. (2004). An Assessment of the Effectiveness of Teaching Test-Taking Strategies for Multiple-Choice English Reading Comprehension Test. Occasional Papers Vol.8, December, 1999. http://www.mahidol.ac.th/sc/sclg/info.html.

White, Tom. (2004). Help is Available for "Test Anxiety." Northern Arizona University: http://www. nau. edu/fronshe/test-anxiety/helplist.html.

Wiersma, William and Stephen G. Jurs. (1990). Educational Measurement and Testing. Massachusetts: Allyn \& Bacon. 